\title{
Małżeństwa mieszkańców katolickiej parafii Mosty koło Jabłonkowa w „długim wieku XIX”*
}

\begin{abstract}
Abstrakt: Głównym celem artykułu jest przedstawienie kwestii związanych z zawieraniem małżeństw w katolickiej parafii w Mostach koło Jabłonkowa w XIX wieku. W tekście omówiono liczbę zawieranych małżeństw oraz ich okoliczności, wpływ sytuacji społecznej i gospodarczej na liczbę małżeństw w latach 1791-1910. Punkt wyjścia dla rozważań stanowią badania metryk ślubnych. Ważnym celem opracowania jest wykazanie przydatności analizy demograficznej dla wyjaśnienia przyczyn i konsekwencji przemian demograficznych w kontekście postępującego procesu industrializacji.

Słow a kluczowe: demografia historyczna, małżeństwo, parafia katolicka w Mostach koło Jabłonkowa
\end{abstract}

Wstęp

Parafia katolicka w Mostach koło Jabłonkowa leżała na obszarze, na którym dużą rolę społeczno-gospodarczą odgrywało rolnictwo. Jednak w drugiej połowie XIX wieku zaczął sie tutaj rozwijać przemysł ciężki, głównie hutnictwo. Z biegiem czasu na terenie tym ukształtowało się Zagłębie Ostrawsko-Karwińskie. Rozwój przemysłu spowodował poważne zmiany społeczne.

Mosty początkowo należały do parafii w Jabłonkowie. Reformy wprowadzane przez cesarza Józefa II doprowadziły do podziału parafii jabłonkowskiej. W wy-

* Artykuł powstał w ramach projektu SGS11/FF/2017-2018 „Hospodářské a sociálnídějiny vybraných lokalit Moravy a Slezska v 18.-20 stoletî” prowadzonego na Wydziale Filozoficznym Uniwersytetu Ostrawskiego. 
niku tego procesu w 1785 roku utworzono parafię Mosty, która należała do diecezji wrocławskiej ${ }^{1}$.

Ślub w społeczności katolickiej był bardzo ważnym wydarzeniem w życiu człowieka. Tym uroczystym aktem człowiek zamykał dotychczasowy etap życia, otwierając zupełnie nowy jego rozdział. $Z$ zawarciem małżeństwa wiązały się zazwyczaj liczne rytuały, często odmienne $\mathrm{w}$ różnych regionach. Akt zawarcia małżeństwa składał się z kilku etapów, były to: zaloty (zolyty), zaręczyny (namowy), ogłoszenie zapowiedzi (ogłoški), wywodziny (vyvodzani), oczepiny (čepjeni) itd. ${ }^{2}$ Śluby zawierano $\mathrm{z}$ reguły $\mathrm{w}$ poniedziałki i wtorki, natomiast $\mathrm{w}$ Mostach, aż do lat 30 . $\mathrm{XX}$ wieku - we wtorki i w środy ${ }^{3}$. W związku ze wzrostem poziomu zatrudnienia w zakładach przemysłowych na początku XX wieku śluby zaczęto przesuwać na soboty i niedziele ${ }^{4}$. Z perspektywy roku kościelnego sakramentu tego nie wolno było zawierać w okresie adwentu i wielkiego postu ${ }^{5}$. Natomiast odpowiednim momentem w roku na wchodzenie w związek małżeński był karnawał i miesiące jesienne.

Od 1791 roku rejestry zawieranych małżeństw w Mostach wyróżniała wysoka wartość informacyjna. W księgach zapisywano bowiem rok, miesiąc i dzień zawarcia ślubu. W głównych rubrykach uzupełniano dane osobowe pana młodego i panny młodej. Dzięki temu można poznać ich imiona i nazwiska, miejsce zamieszkania, wyznanie religijne oraz wiek w chwili zawierania małżeństwa. Od 1791 roku w księgach funkcjonowala oddzielna rubryka o dwóch polach, gdzie można było zaznaczyć jedną z dwóch możliwości: wolny/wolna lub wdowiec/wdowa. Dzięki temu badacz może dowiedzieć się, czy zawierane małżeństwo jest pierwszym czy kolejnym. W księdze ślubów zapisywano również imiona i nazwiska oraz stan cywilny świadków, a także imię i nazwisko kapłana udzielającego sakramentu — zaczęło się pojawiać regularnie od początku lat 90 . XVIII wieku. W całym badanym okresie (1791-1910) księgi ślubów były spisywane w języku niemieckim.

W badaniach nad księgami parafialnymi zastosowano metodę ekscerpcji, czyli przepisywania pojedynczych wpisów na wcześniej przygotowane arkusze. W ten

${ }^{1}$ D. Pindur: Vývoj náboženských poměrů. W: Mosty u Jablunkova včera a dnes. Mosty koło Jabłonkowa wczoraj i dziś. Red. R. JEž, D. Pindur. Český Těšín 2014, s. 95.

${ }^{2}$ Więcej szczegółów na temat śląskiego wesela zob.: G. STUDNICKI: Lidové zvyky a obyčeje na Těšinském Slezsku. Obrzędowość doroczna i rodzinna na Śląsku Cieszyńskim. Český Těšín 2011, s. 29-51; L. Dokoupil, L. NesládkovÁ, R. Lipovski: Populace Rakouského Slezska a severovýchodní Moravy v éř modernizace. Ostrava 2014, s. 67-75; J. ŠTıKA, I. STOLAŘík, V. Tomolová: Těšinsko. 3. díl: Rodina a obec. Obyčeje. Lidové léčitelství. Český Těšín-Rožnov pod Radhoštěm 2001, s. 124-153; J. Vyhlídal: Slezská svatba. Opava 1894; J. Vochala: Slezská svatba. Popis a návod k pořádání slezské svatby na slavnostech. Polská Ostrava 1914.

${ }^{3}$ J. ŠTiKa, I. STOLAŘík, V. Tomolová: Těšínsko..., s. 126.

${ }^{4}$ L. Dokoupil, L. Nesládková, R. Lipovski: Populace Rakouského Slezska..., s. 67.

${ }^{5}$ P. Keř кovskŕ: Doba postní. „Protestant. Nezávislý evangelický měsíčník” 2007, 3. Dostępne w Internecie: http://protestant.evangnet.cz/doba-postni (dostęp: 28.03.2016). 
sposób stworzony został duplikat metryki parafialnej ${ }^{6}$. Zastosowano również metodę agregatywną opracowaną przez grupę historyków z Cambridge, kierowanych przez P. Lasletta, D. Eversly'ego i E. Wrigleya. Ta metoda opiera się na agregowaniu miesięcznych i rocznych sum liczby małżonków, urodzonych i zmarłych oraz ich obserwacji w długich przedziałach czasowych ${ }^{7}$.

Podstawowym problemem było ustalenie, ile osób zamieszkujących obszar parafii było wyznania katolickiego. W źródłach znaleziono tylko nieliczne informacje dotyczące liczby katolików, dlatego konieczne było dokonanie szacunkowych obliczeń i zastosowanie interpolacji. Interpolację można rozważać tylko wtedy, gdy odpowiedni rok, dla którego szacujemy brakującą wartość liczbową, mieści się w przedziałach czasowych dwóch niezbyt odległych znanych i dokładnych numerów populacji ${ }^{8}$.

\section{Ogólny współczynnik zawierania małżeństw}

Cechą charakterystyczną wskaźnika zawieranych małżeństw jest - najbardziej bezpośredni spośród wszystkich wskaźników demograficznych - zdolność reagowania na wszelkie zmiany w życiu społecznym, szczególnie te, wynikające z rozwoju gospodarczego ${ }^{9}$. Ogólny współczynnik zawierania małżeństw dla ziem czeskich wskazywał przez cały XIX wiek stałą wartość, z wyjątkiem lat wojen i nieurodzaju. Permanentnie oscylował wokół 8 zawartych małżeństw na 1000 mieszkańców ${ }^{10}$. Analiza ogólnego współczynnika zawierania małżeństw w parafii Mosty w XIX wieku nie była ograniczona przez luki w materiale archiwalnym. Średnia wartość ogólnego współczynnika zawierania małżeństw w latach 1791-1910 osiągnęła 8,7\%o. Jednak pomiędzy poszczególnymi pięcioleciami badanego okresu zaobserwowano pewne wahania.

Po określeniu ogólnego współczynnika zawierania małżeństw w latach 1791— 1910 konieczne było ustalenie liczby ślubów, których w tym okresie w sumie zawarto 1688.

W latach 1791-1795 ogólny współczynnik zawierania małżeństw w parafii Mosty utrzymywał się na poziomie 6,30\%o, a w okresie 1796-1800 stopa ta była

\footnotetext{
${ }^{6}$ E. Maur: Základy historické demografie. Praha 1978, s. 76-79.

7 J. Horskŕ, M. Seligová: Rodina našich předku․ Praha 1997, s. 48-49.

8 Z. Pavlík, J. Rychtaǩíková, A. Šubrtová: Základy demografie. Praha 1986, s. 65; I. ŠotKovsкÝ: Úvod do studia demografie. Ostrava 1996, s. 92.

${ }^{9}$ L. DoKoupIL: Přirozený pohyb obyvatelstva a jeho úloha v populačním vývoji ostravské průmyslové oblasti vobdobí její geneze a počátečního vývoje. Praha 1972, s. 11.

${ }^{10}$ L. KÁrníKovÁ: Vývoj obyvatelstva v českých zemích 1754-1914. Praha 1965, s. 69.
} 
o 4,7 punktu promilowego wyższa i wynosiła 11,00\%o. O ile bowiem współczynnik zawierania małżeństw $\mathrm{w}$ populacji ziem czeskich $\mathrm{w}$ ostatnich dwóch pięcioleciach XVIII wieku wynosił 8,3 oraz $7,90 \%{ }^{11}$, o tyle w parafii Mosty w pierwszej połowie lat 90. XVIII wieku był on o 2 punkty promilowe niższy, w drugiej połowie lat 90. XVIII wieku natomiast o 3,1 punktu promilowego wyższy. Przyczyną niskiego poziomu ogólnego współczynnika zawierania małżeństw w parafii w Mostach w latach 1791-1795 mogła być napięta sytuacja społeczna, wynikająca z wieloletnich sporów między mieszkańcami Mostów a urzędnikami Komory Cieszyńskiej w kwestii użytkowania rozległych terenów górskich i podgórskich, które rozciągały się także na obszarze gminy. Konflikt ostatecznie rozwiązała ugoda regulacyjna zawarta w $1800 \mathrm{roku}^{12}$. Mieszkańcy Mostów jednak utrzymywali się nie tylko z rolnictwa, lecz także z innych dziedzin działalności gospodarczej. Fakt ten może stanowić jedno z możliwych wyjaśnień wysokich wartości współczynnika zawieranych małżeństw w latach 1796-1800, kiedy to mieszkańcy Mostów mieli możliwość znalezienia pracy i źródła utrzymania, np. przy budowie drogi cesarskiej, którą ukończono w 1802 roku $^{13}$.

Na początku XIX wieku widać stabilny poziom ogólnego współczynnika zawierania małżeństw, który w latach 1801-1805 osiągnął wartość 8,40\%, a w latach $1806-1810-7,90 \%$ o. W okresie tym ogólny współczynnik zawierania małżeństw w populacji parafialnej był wręcz identyczny z całymi Czechami. W latach 1806-1810 jego krzywa - w porównaniu z krajową — była tylko o 0,3 punktu promilowego niższa ${ }^{14}$. Dane uzyskane w okresie 1796-1805 w Mostach można porównać z danymi dla Śląska pruskiego, gdzie ogólny współczynnik zawierania małżeństw w latach $1791-1800$ wynosił średnio $8,80 \%{ }^{15}$. Zatem wskaźnik zawierania małżeństw w parafii Mosty był wyższy w stosunku do Śląska pruskiego o 0,9 punktu promilowego.

Od początku drugiego dziesięciolecia aż do końca lat 60. XIX wieku można między poszczególnymi pięcioleciami każdej dekady zauważyć wyraźne różnice w poziomie ogólnych współczynników zawierania małżeństw w populacji parafialnej.

11 Ibidem, s. 336.

12 G. Morcinek: Śląsk. Cuda Polski. Poznań 1933, s. 35-37; J. Spyra: Życie gospodarcze. W: Śląsk Cieszyński w okresie 1653-1848. Oprac. J. Spyra. Cieszyn 2002, s. 142-149; M. ŠmerdA: Císař Josef II. na Těšínsku v roce 1766. „Těšínsko 48” 2005, č. 3, s. 1-7; B. Pitronová: Těšínské Beskydy na sklonku feudalismu. Salašnictví a lesní hospodářství v Těšínských Beskydech na přelomu 18. a 19. století. Publikace Slezského ústavu Československé akademie věd v Opavě 55. Brno 1968; K. Gaura: Mosty u Jablunkova v letech 1648-1848. „Těšínsko 24” 1981, č. 4, s. 17-20.

13 M. KRŮL: Komunikační význam Jablunkovského průsmyku a jeho vliv na život obce. W: Mosty u Jablunkova včera a dnes..., s. 77-78.

14 L. KÁrníková: Vývoj obyvatelstva..., s. 336.

${ }_{15}$ Historia Śląska. T. 2: 1763-1850. Cz. 1: 1763-1806. Red. W. DŁugoborski. Wrocław 1966, s. 37. 
W latach 1811-1815 ogólny współczynnik zawierania małżeństw w parafii Mosty osiągnął 9,10\%o, w następnym okresie jednak spadł do 7,90\%o. Stosunkowo niskie wartości mogły stanowić odbicie niepewnej sytuacji gospodarczej, spowodowanej ciągłymi wojnami ${ }^{16}$. Przyczynę mniejszej liczby ślubów w latach $1815-1818$ stanowiło także - z pewnym opóźnieniem - bankructwo państwa austriackiego, do którego doszło w 1811 roku $^{17}$. Wydarzenia te wywołały inflację, która wprowadziła szereg zmian w układzie sił społecznych wsi cieszyńskiej. Na przedstawicieli warstw biedniejszych spadało najdotkliwsze brzemię rosnących ciężarów publicznych i innych zmian w stosunkach monetarnych oraz gospodarczych ${ }^{18}$. W wyniku zmian warunków ekonomicznych nastąpił krótkotrwały spadek współczynnika zawieranych małżeństw, o czym świadczą częściowo badania przeprowadzone przez R. Lipovskiego i L. Kárníkovą ${ }^{19}$. Również epidemia dyzenterii w letnich miesiącach 1817 roku i związany z nią wysoki wskaźnik umieralności prowadziły do pogorszenia poziomu życia w parafii. L. Fialová podkreślała, że już w okresie 1816-1820 spadek liczby zawieranych małżeństw w skali całych Czech szybko został zrekompensowany $^{20}$. To swoiste wyrównanie znalazło też odzwierciedlenie w populacji katolickiej parafii Mosty koło Jabłonkowa, gdzie liczba ślubów w tych latach wzrosła z 8 w 1816 i 7 w 1817 roku do 15 w 1819 i 19 w 1820 roku. B. Pitronová wskazywała na fakt, że oprócz pierwotnych zjawisk negatywnych wojny napoleońskie przyniosły także zjawiska pozytywne w postaci ogólnego ożywienia gospodarczego i rozwoju produkcji towarowo-pieniężnej, co było spowodowane przede wszystkim wielkim zapotrzebowaniem na produkty rolnicze ${ }^{21}$.

Lata 20. XIX wieku charakteryzowały się podobnym zróżnicowaniem w poziomach ogólnych współczynnika zawierania małżeństw w katolickiej parafii Mosty. W latach 1821-1825 odnotowano wartość 7,20\%o, a w okresie 1826-1830 wartość 9,40\%o. Do wzrostu badanego współczynnika mogło przyczynić się ożywienie gospodarcze w przemyśle i rolnictwie, które dotyczyło całych Czech ${ }^{22}$. W latach 30 . XIX wieku różnica między wartościami ogólnymi współczynników zawierania małżeństw w obu pięcioleciach wynosiła dokładnie 1,80 punktu promilowego, w latach 1831-1835 współczynnik ten osiągnął poziom 8,70\%o, a w okresie 1836-1840

${ }^{16}$ L. Fialová: Vývoj sňatečnosti a plodnosti obyvatelstva českých zemív 19. století. W: Historická demografie 12. Praha 1987, s. 208.

17 B. Pitronová: Těšínsko vletech 1653-1848. W: Nástin dějin Těšínska. Praha-Ostrava 1992, s. 57.

${ }_{18}$ J. Chlebowczy к: Nad Olza. Katowice 1971, s. 13-14; J. Spyra: Dzieje polityczne. W: Ślask Cieszyński w okresie 1653-1848. Oprac. J. Spy R. Cieszyn 2002, s. 99-100.

19 R. Lipovski: Lidé poddanských měst Frýdku a Mistku na sklonku tradiční společnosti (1700_ 1850). Ostrava 2013, s. 108; L. KÁRníková: Vývoj obyvatelstva..., s. 72-73.

${ }^{20}$ L. Fialová: Vývoj sňatečnosti a plodnosti..., s. 208.

${ }^{21}$ B. Pitronová: Těšínsko..., s. 57.

${ }^{22}$ L. KÁRníkovÁ: Vývoj obyvatelstva..., s. 73. 
było to jedynie $6,70 \%$. Kiedy średnie współczynniki zawierania małżeństw w całych Czechach w drugiej połowie lat 30. XIX wieku oscylowały ok. 8,20\%o, ogólny współczynnik zawierania małżeństw w populacji parafii w Mostach utrzymywał się o 1,50 punktu promilowego poniżej średniej dla ziem czeskich. Jednym z powodów takiego stanu rzeczy była nowa epidemia cholery, która szczególnie w latach 1836 i 1837 miała katastrofalne skutki, zwłaszcza na Morawach i Śląsku. W regionach tych zmarło ponad 25 tys. osób ${ }^{23}$. Potwierdza to fakt, że w 1836 roku ogólny współczynnik pozostawał na poziomie $2,70 \%$, co stanowi najniższą jego wartość w całym badanym okresie (1791-1910).

Pięciolecia 1841-1845 i 1846-1850 przyniosły wielkie różnice w wartościach ogólnych współczynników zawierania małżeństw. W pierwszym wspomnianym pięcioleciu współczynnik znajdował się na stosunkowo niskim poziomie $7,50 \%$, jednak już w następnym okresie wzrósł o 2,6 punktu promilowego, dokładnie do $10,10 \%$. Lata 50 . XIX wieku prezentują podobną asymetrię — podczas gdy w okresie 1851-1855 współczynnik zawierania małżeństw wynosił $6,40 \%{ }^{24}$, w drugiej połowie lat 50. odnotowano jego wzrost do wartości 9,00\%o.

Wyraźne wahania ogólnego współczynnika zawierania ślubów w tym okresie spowodowane były latami głodu, bezrobociem oraz nowymi falami epidemii (tyfus, cholera, ospa, dyzenteria, gruźlica itd.), które na ziemi cieszyńskiej trwały, z niewielkimi przerwami, aż do 1856 roku $^{25}$, a które najbardziej dotkliwie odczuli właśnie mieszkańcy górzystych obszarów Beskidów cieszyńskich. Ciężar owych kryzysów określają także wartości ogólnych współczynników zawierania małżeństw dla populacji parafialnej, kiedy w ciągu trzech lat w okresie 1851-1855 odnotowywano niskie wartości, sięgające najwyżej ok. 5,00\%o. Pojawiły się też deformacje struktury populacji w segmentach wiekowych, spowodowane epidemiami na początku lat głodu ${ }^{26}$. L. Dokoupil zwrócił uwagę, że liczebność populacji gmin beskidzkich, jeszcze przed początkiem pierwszej fali epidemii w latach 1847-1848, pozostawała poniżej średnich wartości współczynników urodzeń i ślubów dla mieszkańców ziem czeskich. Szczególnie ziemia jabłonkowska już w latach 40. XIX wieku wykazywała znacznie niższe współczynniki zawierania małżeństw (ok. 5,00\%o), a w związku z tym także niższe współczynniki urodzeń $(30,00 \%)^{27}$. W populacji parafii katolickiej Mosty koło Jabłonkowa odnotowano jednak nieco wyższe wskaźniki ogólnych współczynników zawierania małżeństw: w latach 40 . było to średnio $8,80 \%$,

${ }^{23}$ Ibidem, s. 74.

24 L. Turoň: Vývoj přirozené měny obyvatelstva evangelické farnosti Bystřice nad Olší ve statistické éře. Diplomová práce na Katedře historie Filozofické fakulty Ostravské univerzity v Ostravě. Ostrava 2016, s. 36.

25 K. PopioŁek: Historia Śląska. Od pradziejów do 1945 roku. Katowice 1972, s. 157.

${ }^{26}$ L. Dokoupil: Důsledky hladových let v polovině 19. století pro vývoj populace Těšínských Beskyd. „Sborník prací Pedagogické fakulty v Ostravě, řada C-10”. Ostrava 1975, s. 70.

27 Ibidem, s. 66. 
a w latach 50. - 7,70\%o. Podobnie też ogólny współczynnik urodzeń oscylował wokół wyższych wartości, w tych samych dziesięcioleciach sięgał średnio 33,90\%o oraz 32,90\%o. Mówiąc o ogólnych współczynnikach zawierania małżeństw w populacji parafialnej w poszczególnych latach, lata 40. i 50. XIX wieku były czasem braku stabilności. Przykładem tego jest porównanie lat 1855 i 1856, w pierwszym roku współczynnik zawierania małżeństw oscylował wokół 5,70\%o, w roku 1856 był już o 10,7 punktu promilowego większy.

Szczególnym zjawiskiem jest wyraźny wzrost współczynnika zawierania małżeństw w katolickiej populacji parafii Mosty w okresie 1848—1850, który wynosił 12,20\%. Na uwagę zasługuje szczególnie rok 1850, w którym odnotowano 18 ślubów na 1000 mieszkańców. L. Dokoupil podkreślał, że fenomen ten był znamienny dla mieszkańców Beskidów, jednocześnie dodał, że wiązał się on z poprawą warunków bytowych po zbiorach w 1848 roku, co przełożyło się na wzrost liczby zawieranych ślubów, które odkładano przez kilka lat. Uwaga ta dotyczyła szczególnie ślubów drugich i kolejnych. Wśród mieszkańców Beskidów odsetek drugich i kolejnych ślubów w 1848 roku stanowił ponad połowę wszystkich zawartych małżeństw, natomiast w 1850 roku nadzwyczajny wzrost liczby zawieranych małżeństw na ziemi jabłonkowskiej osiągnął swoje apogeum $(16,00 \%)^{28}$. Badania prowadzone na danych katolickiej parafii Mosty koło Jabłonkowa potwierdziły tę tezę w odniesieniu do przywołanych lat. W tej parafii najwyższy wskaźnik drugich i kolejnych ślubów w latach 1846-1850 stwierdzono w 1848 roku, w którym zawarto 52,90\% takich małżeństw. W latach 1849 i 1850 odsetek tego typu małżeństw nie był już tak wysoki, dochodził bowiem do 33,30\% oraz 21,40\%. Można się domyślać, że chodziło właśnie o tzw. odłożone śluby z drugiej połowy lat 40., które nie doszły do skutku ze względu na trudną sytuację gospodarczą i społeczną. Niezwykle wysokiej liczbie zawieranych małżeństw $\mathrm{w}$ ramach populacji parafialnej towarzyszył stosunkowo wysoki współczynnik urodzeń (w roku 1850 wynosił 48,20\%o ${ }^{29}$.

W latach 60. XIX wieku ostatni raz odnotowano wyraźną różnicę w pięcioletnich wartościach ogólnych współczynników zawierania małżeństw w parafii Mosty. Podczas gdy w pierwszej połowie tej dekady współczynnik zawierania małżeństw utrzymywał się średnio na poziomie 8,30\%, w okresie 1866-1870 wzrósł on do 13,90\%o, co stanowiło jednocześnie najwyższy odnotowany ogólny współczynnik zawierania małżeństw w populacji katolickiej parafii Mosty koło Jabłonkowa w latach 1791-1910. W porównaniu z wartościami ogólnymi wskaźników zawierania małżeństw w drugiej połowie lat 60. na ziemiach czeskich, parafia Mosty lokowała się powyżej średniej, przekraczając ją dokładnie o 5,0 punktów promilowych ${ }^{30}$. W 1869 roku odnotowano najwyższy ogólny współczynnik zawierania małżeństw

\footnotetext{
${ }^{28}$ Ibidem, s. 70.

${ }^{29}$ L. Turoñ: Vývoj prírozené..., s. 36.

${ }^{30}$ L. KÁRníKová: Vývoj obyvatelstva..., s. 336.
} 
w jednym roku, który osiągnął $18,80 \%{ }^{31}$. W następnym roku wartość ta również pozostała wysoka $(17,50 \%)$.

Od lat 70. XIX wieku aż do 1910 roku w każdym dziesięcioleciu poszczególne współczynniki zawierania małżeństw były stosunkowo wyrównane w pięcioletnich okresach. W pierwszej połowie lat 70. XIX wieku wynosił on $9,40 \%$, natomiast $\mathrm{w}$ drugiej połowie tego dziesięciolecia wzrósł do $10,20 \%{ }^{32}$. W pięcioleciu 1871-1875 współczynnik zawierania małżeństw był nieznacznie wyższy od ogólnego współczynnika dla Śląska austriackiego $(8,80 \%$ ) i powiatu politycznego cieszyńskiego $(9,20 \%$ ). W okresie 1876-1880 wartość współczynnika zawierania małżeństw w parafii była już wyraźnie wyższa od tych samych współczynników ogólnych w przypadku regionu historycznego (różnica 2,7 punktu promilowego) oraz powiatu politycznego (różnica 1,8 punktu promilowego) ${ }^{33}$. Dane dotyczące wartości ogólnych współczynników zawierania małżeństw ustalono dla poszczególnych lat pierwszej połowy lat 70., kiedy to w czasie 1871-1873 wartość ta przekraczała granicę $10,00 \%$, w roku 1873 sięgając nawet 12,00\%o. Jednak w latach 1874-1875 nastąpił duży spadek liczby zawieranych małżeństw do 6,00\%o oraz 6,50\%o. Można założyć, że przyczyną wysokich wartości ogólnych współczynników zawierania małżeństw wśród mieszkańców parafii na przełomie lat 60. i 70. XIX wieku było polepszenie się warunków bytowych, dzięki budowie połączenia kolejowego, tzw. Kolei Koszycko-Bogumińskiej, której budowa przypadła na lata $1867-1872^{34}$. Wielu mieszkańców parafii Mosty znalazło wówczas pracę przy budowie magistrali kolejowej ${ }^{35}$. L. Kárníková wskazywała również, że w skali całych Czech koniec lat 60. i początek 70. XIX wieku to czas koniunktury gospodarczej, której towarzyszył wzrost liczby zawieranych małżeństw. Lata 1872 i 1873 zwiastowały natomiast początek wielkiego kryzysu, który pociągnął za sobą ogromny wzrost bezrobocia ${ }^{36}$. Niekorzystne zmiany i kryzys ekonomiczny zapoczątkował krach na giełdzie wiedeńskiej w $1873 \mathrm{roku}^{37}$. Niskie wartości ogólnych współczynników zawierania małżeństw w populacji parafii w latach 1874 i 1875 były opóźnioną reakcją na ten kryzys. Jednak w poszczególnych latach drugiej połowy omawianego dziesięciolecia ogólny współczynnik zawierania małżeństw w populacji parafii nie

${ }^{31}$ L. DokoupiL: Obyvatelstvo ostravské průmyslové oblasti do sčítání 1869. W: Spisy Pedagogické fakulty v Ostravě. Sv. 57. Praha 1987; IDEM: $Z$ díla historického demografa, Ostravská univerzita v Ostravě. Ostrava 2015, s. 477-483; IDEM: Demografický vývoj ostravské prưmyslové oblasti v období její geneze a počátečního vývoje: závěrečná výzkumná zpráva, úkol VIII-3-10/1. Pedagogická fakulta v Ostravě. Ostrava 1972, s. 156-160.

${ }^{32}$ L. Turoň: Vývoj přirozené..., s. 36.

${ }^{33}$ L. Dokoupil, L. Nesládková, R. Lipovski: Populace Rakouského Slezska..., s. 78.

${ }^{34}$ M. KRŮL: Komunikační význam Jablunkovského..., s. 79.

35 J. Wojt l la: Pamétní kniha Mostů u Jablunkova. 1. díl: Mosty u Jablunkova 1953-1975. Mosty u Jablunkova 1977, s. 14.

${ }^{36}$ L. KÁRNíková: Vývoj obyvatelstva..., s. 131, 336.

37 L. DokoupiL: Demografický vývoj ostravské..., s. 102. 
spadł poniżej 8,00\%o. Porównanie liczby zawieranych małżeństw w parafii Mosty ze średnimi dla ziem czeskich $^{38}$ prowadzi do stwierdzenia, że mieszkańcy Mostów w latach 1876-1880 zawierali więcej związków małżeńskich o 2,3 punktu promilowego. Trzeba też zaznaczyć, że przemysł na ziemi cieszyńskiej, np. górnictwo czy hutnictwo, ucierpiał stosunkowo mniej wskutek kryzysu niż na innych obszarach ziem czeskich. O lepszej sytuacji socjalnej na tych ziemiach mógł także zadecydować tutejszy kamieniołom. Początki kamieniarstwa datuje się od ukończenia budowy Kolei Koszycko-Bogumińskiej, dzięki której można było eksportować kruszywo do wielu regionów państwa Habsburgów ${ }^{39}$.

W latach 80. XIX wieku, w przeciwieństwie do wcześniejszego dziesięciolecia, poziom ogólnego współczynnika zawierania małżeństw w parafii Mosty koło Jabłonkowa wyraźnie się obniżył, jednak w obu pięcioleciach pozostał stosunkowo stały. W latach 1881 - 1885 wynosił 7,10\%o, natomiast w okresie 1886-1890 zwiększył się do 7,60\%o. W obu tych pięcioleciach ogólny wskaźnik zawierania małżeństw w parafii Mosty był zawsze niższy od odnotowanego na Śląsku austriackim i w powiecie politycznym cieszyńskim. W latach $1871-1875$ różnica wynosiła 0,8 oraz 1,6 punktu promilowego, a w latach 1876-1880 0,3 i 0,7 punktu promilowego $^{40}$. Zdaniem L. Kárníkovej, negatywny wpływ na rozwój demograficzny lat 80. XIX wieku wywarł kryzys agrarny, który dotknął nie tylko regiony zorientowane na uprawę zbóż, lecz także urodzajne niziny rolnicze $\mathrm{z}$ rozwiniętym przemysłem cukrowniczym, sektorem buraczanym i uprawą warzyw. Przeciągający się kryzys agrarny, którego skutki odczuwano jeszcze w latach 90. XIX wieku, prowadził do zmniejszania ilości siły roboczej, a następnie obniżenia wynagrodzeń ${ }^{41}$. Oprócz tego zmniejszył się rynek zbytu drewna opałowego i zmieniły się procesy technologiczne w zakładach Huty Trzynieckiej, czego efektem był kryzys w wyrębie lasów, stanowiącym dla wielu mieszkańców Mostów źródło utrzymania. Całe rodziny wróciły do uprawy lnu, tkactwa, a także produkcji przedmiotów z kamienia i drewna ${ }^{42}$. Te niesprzyjające warunki doprowadziły do tego, że niektórzy mieszkańcy Mostów wyemigrowali za ocean, głównie do Kanady i Stanów Zjednoczonych Ameryki Północnej, gdzie znaleźli zatrudnienie jako robotnicy rolni lub przemysłowi ${ }^{43}$.

W latach 90. XIX wieku ogólny współczynnik zawierania małżeństw ponownie wzrósł i aż do 1910 roku oscylował w granicach 8,50-9,30\%o. W pierwszej połowie lat 90. utrzymywał się na poziomie 9,00\%o, natomiast w latach $1896-1900$

\footnotetext{
${ }^{38}$ L. KÁRNÍKOVÁ: Vývoj obyvatelstva..., s. 336.

${ }^{39}$ M. MYšKa: Region a industrializace, studie k dějinám industrializace Slezska (1800-1918). Ostrava 2014, s. 152 i 205.

${ }^{40}$ L. Dokoupil, L. Nesládková, R. Lipovski: Populace Rakouského Slezska..., s. 78.

${ }^{41}$ L. KÁRNíKovÁ: Vývoj obyvatelstva..., s. 191, 213-216.

${ }^{42}$ R. JEž: Politicko-správní vývoj a hospodářské poměry. W: Mosty u Jablunkova včera a dnes..., s. $24-25$.

${ }^{43}$ K. Gaura: Mosty u Jablunkova v letech 1848-1918 (3. část). „Těšínsko 38” 1995, č. 1, s. 15.
} 
dał się zauważyć lekki jego spadek do 8,50\%o. Na początku XX wieku doszło do stopniowego wzrostu tego wskaźnika w parafii Mosty. W latach 1901-1905 wynosił on 8,90\%, natomiast w okresie 1906-1910 wzrósł do 9,30\%. W latach 18911910 dane ogólnego współczynnika zawierania małżeństw dla mieszkańców parafii w Mostach wykazywały - w porównaniu ze średnią dla całych Czech - za każdym razem wyższe wartości. Największa różnica została odnotowana w latach 1891-1895 i 1906-1910, w których wartość ogólnego współczynnika zawierania małżeństw w populacji parafialnej przewyższała krajową o 1,3 oraz 1,6 punktu promilowego. Na wzrost liczby zawieranych małżeństw w populacji parafii na przełomie XIX i XX wieku miał niewątpliwie wpływ rozwijający się w tym regionie przemysł ciężki. Wówczas to w hutach w Trzyńcu, kopalniach w regionie karwińsko-ostrawskim i na Kolei Koszycko-Bogumińskiej wielu członków badanej parafii znajdowało zatrudnienie, czego efektem była stabilna praca i dochód, a to przekładało się na poprawę lokalnej sytuacji społecznej ${ }^{44}$. Wysokiej liczbie zawieranych małżeństw w latach 90. XIX wieku i na początku XX stulecia towarzyszył nadzwyczaj wysoki współczynnik urodzeń, który w tamtym dwudziestoleciu oscylował w granicach $43,50-47,40 \%$. Znamienną tendencją w ostatnich dziesięcioleciach istnienia monarchii habsburskiej był powszechny spadek ogólnych współczynników zawierania małżeństw we wszystkich regionach. Jeśli mowa o Śląsku austriackim, od początku XX wieku odnotowano stopniowy spadek liczby zawieranych związków małżeńskich z 8,50\%o w ostatnim pięcioleciu XIX wieku do 8,00\%o i 7,70\%o w latach 1901-1905 oraz 1906-1910. Podobne wartości wskazanych współczynników ogólnych, chociaż nieco wyższe, osiągał także powiat polityczny cieszyński. W ramach tej jednostki administracyjnej można było zaobserwować stopniowy spadek wskaźnika zawierania małżeństw z 9,00\%o w okresie 1896-1900 do 8,30\%o i 7,60\%o w pierwszych dwóch pięcioleciach XX wieku (1900-1910) ${ }^{45}$. Porównując dane z parafii Mosty z danymi ogólnymi, można stwierdzić, że liczba zawieranych małżeństw na przełomie XIX i XX wieku wyraźnie odchyliła się od opisanej tendencji rozwojowej. W pierwszych latach XX wieku zarejestrowano w badanej populacji wzrost współczynnika zawierania małżeństw z 8,50\%o w okresie 1896-1900 do 8,90\%o w latach 1901-1905 i 9,30\%o w następnym pięcioleciu (1906-1910). W parafii Mosty odnotowano na przełomie XIX i XX wieku znacznie wyższe wskaźniki liczby zawieranych małżeństw, niż wynosiła średnia dla ziemi cieszyńskiej i dla całego Śląska pozostającego pod władzą Habsburgów ${ }^{46}$. Kształtowanie się ogólnego współczynnika zawierania małżeństw w parafii Mosty koło Jabłonkowa w całym badanym okresie ilustruje wykres 1 .

\footnotetext{
${ }^{44}$ J. Wojtyla: Pamětní kniha Mostů u Jablunkova. 1. díl..., s. 19-21.

${ }^{45}$ L. Dokoupil, L. Nesládková, R. Lipovski: Populace Rakouského Slezska..., s. 76-80.

${ }^{46}$ L. TuroŇ: Vývoj prrirozené..., s. 38-39.
} 


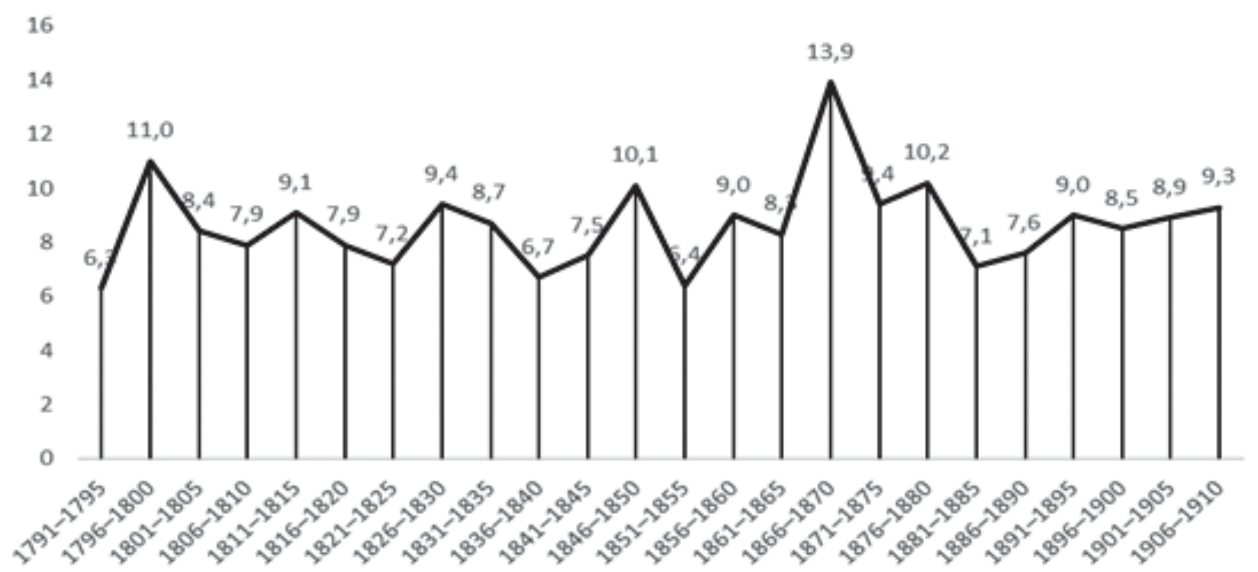

Wykres 1. Ogólny współczynnik zawierania małżeństw w parafii Mosty koło Jabłonkowa w poszczególnych pięcioleciach (1791-1910)

\section{Odsetek pierwszych, drugich i kolejnych małżeństw}

W demografii historycznej badacz styka się z dwoma podstawowymi typami małżeństw: małżeństwami pierwszymi oraz małżeństwami drugimi i kolejnymi. Małżeństwo pierwsze zawierane było przez dwie osoby stanu wolnego, czyli kawalera i pannę. Do kategorii małżeństw drugich i kolejnych zalicza się kilka typów małżeństw: kawalera $\mathrm{z}$ wdową, wdowca $\mathrm{z}$ panną czy wdowca $\mathrm{z}$ wdową, a ponadto także małżeństwa zawarte przez osoby rozwiedzione ${ }^{47}$. Stosunkowo częste były przede wszystkim małżeństwa drugie, które stanowiły 20-25\% wszystkich ślubów. Kolejne małżeństwa już nie były tak częste. W ciągu XIX wieku odsetek drugich i kolejnych małżeństw stopniowo malał ${ }^{48}$.

W latach 1791-1910 w parafii Mosty zawarto łącznie 1688 ślubów, z czego 1246 $(73,8 \%)$ stanowiły małżeństwa pierwsze. Odsetek drugich i kolejnych małżeństw wynosił w całym wyznaczonym okresie $26,20 \%$, co odpowiada 443 zawartym związkom małżeńskim (por. tabela 1$)^{49}$.

W analizowanym przedziale czasowym (1791-1910) struktura zawieranych małżeństw była w dużej mierze zmienna. W poszczególnych pięcioleciach okresu

47 L. Dokoupil, L. Nesládková, R. Lipovski: Populace Rakouského Slezska..., s. 90.

48 L. Fialová: Století demografické statistiky. W: Dějiny obyvatelstva českých zemí. Praha 1996, S. 164.

49 L. Turoñ: Vývoj přirozené..., s. 40. 
$1791-1850$ odsetek pierwszych małżeństw oscylował w granicach $58,20-77,90 \%$, natomiast odsetek drugich i kolejnych małżeństw mieścił się w przedziale 22,10_$41,80 \%$. Od początku lat 50. XIX wieku aż do 1910 roku można zaobserwować pewne wahania w stosunkach tych dwóch kategorii małżeństw w poszczególnych pięcioleciach, ale różnice nie są już tak wyraźne. Odsetek małżeństw pierwszych w latach $1851-1910$ wynosił $65,70-83,10 \%$, a odsetek par zawierających małżeństwo drugie i kolejne mieścił się w przedziale 16,90-34,30\%.

Tabela 1

Liczba zawieranych pierwszych, drugich i kolejnych małżeństw w parafii katolickiej Mosty koło Jabłonkowa w poszczególnych pięcioleciach (1791-1910)

\begin{tabular}{|c|c|c|c|c|c|c|}
\hline \multirow{2}{*}{ Okres } & \multicolumn{2}{|c|}{ Pierwsze śluby } & \multicolumn{2}{|c|}{ Drugie i kolejne śluby } & \multicolumn{2}{|c|}{ Łącznie } \\
\hline & liczba & $\%$ & liczba & $\%$ & liczba & $\%$ \\
\hline $1791-1795$ & 26 & 68,4 & 12 & 31,6 & 38 & 100 \\
\hline $1796-1800$ & 53 & 76,8 & 16 & 23,2 & 69 & 100 \\
\hline $1801-1805$ & 32 & 58,2 & 23 & 41,8 & 55 & 100 \\
\hline $1806-1810$ & 37 & 69,8 & 16 & 30,2 & 53 & 100 \\
\hline $1811-1815$ & 38 & 61,3 & 24 & 38,7 & 62 & 100 \\
\hline $1816-1820$ & 42 & 76,4 & 13 & 23,6 & 55 & 100 \\
\hline $1821-1825$ & 39 & 76,5 & 12 & 23,5 & 51 & 100 \\
\hline $1826-1830$ & 53 & 77,9 & 15 & 22,1 & 68 & 100 \\
\hline $1831-1835$ & 42 & 65,6 & 22 & 34,4 & 64 & 100 \\
\hline $1836-1840$ & 31 & 62,0 & 19 & 38,0 & 50 & 100 \\
\hline $1841-1845$ & 37 & 64,9 & 20 & 35,1 & 57 & 100 \\
\hline $1846-1850$ & 56 & 71,8 & 22 & 28,2 & 78 & 100 \\
\hline $1851-1855$ & 35 & 70,0 & 15 & 30,0 & 50 & 100 \\
\hline $1856-1860$ & 51 & 70,8 & 21 & 29,2 & 72 & 100 \\
\hline $1861-1865$ & 44 & 65,7 & 23 & 34,3 & 67 & 100 \\
\hline $1866-1870$ & 92 & 80,0 & 23 & 20,0 & 115 & 100 \\
\hline $1871-1875$ & 54 & 68,4 & 25 & 31,6 & 79 & 100 \\
\hline $1876-1880$ & 72 & 81,8 & 16 & 18,2 & 88 & 100 \\
\hline $1881-1885$ & 48 & 75,0 & 16 & 25,0 & 64 & 100 \\
\hline $1886-1890$ & 59 & 83,1 & 12 & 16,9 & 71 & 100 \\
\hline $1891-1895$ & 67 & 75,3 & 22 & 24,7 & 89 & 100 \\
\hline $1896-1900$ & 70 & 77,8 & 20 & 22,2 & 90 & 100 \\
\hline $1901-1905$ & 80 & 81,6 & 18 & 18,4 & 98 & 100 \\
\hline $1906-1910$ & 87 & 82,9 & 18 & 17,1 & 105 & 100 \\
\hline $1791-1910$ & 1245 & 73,8 & 443 & 26,2 & 1688 & 100 \\
\hline
\end{tabular}

Źródło: Archiwum Ziemskie w Opawie, Parafia Rzymskokatolicka Mosty koło Jabłonkowa, nr inw. 2939, sygn. Ja III 3 (lata 1786-1901), sygn. Ja III 9 (lata 1902-1947), metryki ślubów. 
Również w parafii Mosty najwięcej zawierano pierwszych małżeństw, ich liczba była najwyższa na przełomie lat 60./70. XIX wieku i na początku XX wieku. Przykładowo w latach 1801-1820 stosunek pierwszych małżeństw do małżeństw drugich i kolejnych można wyrazić proporcją 66,40\% :33,60\%, a w latach $1890-1910$ stosunek ten wynosił 79,40\% : 20,60\%. Przedstawione wyniki są zgodne z ogólną tendencją stopniowego obniżania się odsetka powtórnych małżeństw w drugiej połowie XIX i na początku XX wieku ${ }^{50}$. Interesujące wyniki daje porównanie danych z parafii Mosty z uzyskanymi dla nieodległej gminy Bukowiec, a więc z dwóch podgórskich wsi. W odróżnieniu od parafii Mosty, Bukowiec miał charakter pasterski i był bardziej oddalony od cywilizacji. Dlatego jeszcze na początku XX wieku w Bukowcu odsetek drugich i kolejnych małżeństw wynosił $30-40 \%{ }^{51}$. Od drugiej połowy lat 70. XIX wieku w badanej parafii w żadnym pięcioleciu odsetek powtórnych małżeństw nie przekraczał $30 \%$, natomiast na początku XX wieku wynosił on poniżej 20\%. Na podstawie tych wyników i dzięki zgodności z powszechną tendencją charakter gminy Mosty koło Jabłonkowa, będącej jeszcze w 1910 roku wyłącznie katolicką wsią ${ }^{52}$, można oznaczyć jako zindustrializowany, do czego wyraźnie przyczyniła się lokalizacja przy trasie kolejowej. Tezę tę potwierdza fakt, że w drugiej połowie XIX wieku również na całej ziemi trzynieckiej wyraźne widać oddziaływanie powszechnego trendu - o ile w samym hutniczym Trzyńcu odsetek powtórnych małżeństw sięgał 21\%, w przyległej Wędryni stosunek małżeństw pierwszych do drugich i kolejnych wynosił $73 \%: 27 \%$, natomiast w odległej Piosecznej $71 \%: 29 \%{ }^{53}$. Wspomniana już powszechna tendencja przenikała do populacji ewangelickiej parafii Bystrzyca nad Olzą, gdzie w latach 90. XIX wieku i w pierwszym dziesięcioleciu następnego stulecia wyliczony stosunek pierwszych ślubów do drugich i kolejnych wynosił $72 \%: 28 \%{ }^{54}$.

Jeśli chodzi o drugie i kolejne małżeństwa, przeważały śluby między wdowcami i pannami. Ten typ związków małżeńskich tworzył połowę wszystkich drugich i kolejnych małżeństw. Łącznie mowa o 225 parach zawierających takie związki, co stanowiło 50,80\% wszystkich zawartych drugich i kolejnych małżeństw.

Drugą najczęstszą grupą związków były małżeństwa między wdowami i kawalerami. Ich odsetek w ogólnej liczbie wszystkich małżeństw drugich i kolejnych wynosił 30,20\%, konkretnie chodziło o 134 pary żyjące w tego typu związkach.

\footnotetext{
${ }^{50}$ L. Fialová: Století demografické statistiky..., s. 164.

${ }^{51}$ N. Rachfalíková: Demografický vývoj obce Bukovec v letech 1795-1930. Diplomová práce na Pedagogické fakultě v Ostravě. Ostrava 1987, s. 58.

${ }_{52}$ Spezialortsrepertorium von Schlesien. Bearbeitetauf Grund der Ergebnisse der Volkszählungvom 31. Dezember 1910. Wien 1917, s. 28.

${ }^{53}$ Z. Litnerová: Demografický vývoj Třinecka v letech 1839-1900 na př́íkladě Třince, Vendryně a Písečné. Diplomová práce na Pedagogické fakultě v Ostravě. Ostrava 1988, s. 41.

${ }^{54}$ L. Turoň: Vývoj přirozené..., s. 40-42.
} 
Uzyskane wyniki badań potwierdzają powszechność sytuacji, w której mężczyźni jako wdowcy mieli wyższą wartość na rynku matrymonialnym i możliwość większego wyboru. Dlatego też śluby wdowców z pannami były częstsze niż wdów z kawalerami, szczególnie jeśli kobieta miała więcej dzieci. Ważną rolę w tych przypadkach odgrywała pozycja społeczna i ekonomiczna wdowy ${ }^{55}$. Podczas gdy za wdowców wychodziła za mąż mniej więcej $1 / 3$ panien, małżeństwo $\mathrm{z}$ wdową zawierał jedynie co 20 . kawaler ${ }^{56}$.

Najmniej typową grupę stanowią małżeństwa zawarte przez wdowę i wdowca. Łącznie w badanym okresie (1791-1910) było ich 84, czyli 19\% wszystkich drugich i kolejnych małżeństw.

W całym badanym okresie nie odnotowano w metrykach małżeństwa, w którym przynajmniej jedna z osób była rozwiedziona.

Można zauważyć, że liczba drugich i kolejnych małżeństw wzrastała szczególnie po wojnach (np. w pięcioleciach 1801-1805 czy 1811-1815 odsetek powtórnych ślubów wynosił odpowiedno: $41,80 \%$ oraz $38,70 \%$ ), po epidemiach (np. po powtarzających się epidemiach cholery w latach 30., kiedy to odsetek tego typu małżeństw wynosił średnio 36,20\%) czy kryzysach społecznych i ekonomicznych (np. w latach 1871-1875, kiedy zawarto 31,60\% drugich i kolejnych małżeństw). Natomiast najniższą liczbę drugich i kolejnych małżeństw odnotowano w okresie koniunktury gospodarczej w rolnictwie i przemyśle (np. lata 20. XIX wieku, kiedy odsetek ten wahał się w granicach $22,10-23,50 \%$ ), a także w czasie rozkwitu zakładów przemysłu ciężkiego w badanym regionie Śląska Cieszyńskiego (przełom XIX i XX wieku).

\section{Wiek nowożeńców w chwili zawierania związku małżeńskiego}

Wiek państwa młodych w rejestrach ślubów podawany był od czasów józefińskiej reformy rejestrów w 1784 roku. Obojgu partnerom wpisywano wiek, który osiągnęli w dniu ich ostatnich (przed ślubem) urodzin ${ }^{57}$. Średni wiek zawierania małżeństw można wyliczyć, dzieląc sumę wieku osób zawierających małżeństwo przez ich liczbę i dodając do wyniku $0,5^{58}$.

W celu określenia średniego wieku zawierania małżeństwa w parafii Mosty zostały wybrane cztery dziesięcioletnie próby obejmujące lata 1791-1800, 1831-

${ }^{55}$ L. Dokoupil, L. Nesládková, R. Lipovski: Populace Rakouského Slezska..., s. 91-92.

${ }^{56}$ L. Fialová: Století demografické statistiky..., s. 164.

${ }^{57}$ L. Dokoupil, L. NesládkovÁ, R. Lipovski: Populace Rakouského Slezska..., s. 94.

${ }^{58}$ E. Maur: Základy historické..., s. 122. 
1840, 1871-1880 i 1901-1910. W pierwszym dziesięcioleciu odbyło się 107 ślubów, w drugim - 114, w trzecim - 167, a w czwartym - 203 śluby.

W przypadku mężczyzn zaobserwować można niewielkie podwyższenie wieku, w jakim zawierali pierwsze małżeństwo, z 24 lat i 2 miesięcy od końca XVIII wieku do 26 lat i 5 miesięcy pod koniec lat 30. XIX stulecia. Ponowne obniżenie wieku mężczyzn zawierających pierwszy związek małżeński przyniosły lata 70. XIX wieku, kiedy średni wiek wynosił 24 lata i 5 miesięcy. Na początku XX stulecia wiek zawierania małżeństw w przypadku mężczyzn nieco się podniósł - do ok. 25 lat i 8 miesięcy. Średni wiek panien zawierających pierwsze małżeństwo w ostatniej dekadzie XVIII wieku był stosunkowo niski - ok. 21 lat (20 lat i 7 miesięcy). Pod koniec lat 30. XIX wieku wskaźnik ten podniósł się do pełnych 23 lat. W latach 70. odnotowano wyraźne obniżenie średniej wieku kobiet wchodzących po raz pierwszy w związek małżeński do 20 lat i 5 miesięcy. Pierwsze dziesięciolecie XX wieku przyniosło niewielki wzrost wieku kobiet w chwili zawierania pierwszego małżeństwa do 22 lat i 3 miesięcy. Ciekawostkę stanowi fakt, że w trzech pozostałych dziesięcioleciach (1831-1840, 1871-1880 i 1901-1910) różnica wieku była taka sama, panowie młodzi zawierający pierwsze małżeństwo byli średnio o 3 lata i 7 miesięcy starsi od panien młodych. Dane, które analizowano, potwierdzają wyniki badań dotyczących rozwoju ziem czeskich, jednak obniżenie wieku zawierania pierwszego małżeństwa w próbach $\mathrm{z}$ lat 70. XIX stulecia i z początku XX wieku było bardziej wyraźne w porównaniu z danymi dla całych Czech ${ }^{59}$.

Średni wiek mężczyzn ponownie zawierających małżeństwa był wyższy w poszczególnych dziesięcioletnich próbach. Wprawdzie wiek ten oscyluje wokół 40 lat, ale w trzech przypadkach mężczyźni przekroczyli tę granicę. Już w latach 17911800 odnotowano stosunkowo zaawansowany wiek mężczyzn w chwili zawierania kolejnego małżeństwa, wynosił on niemal 42 lata (41 lat i 9 miesięcy). Dla porównania, w ewangelickiej parafii w Bystrzycy nad Olzą wiek mężczyzn zawierających drugi lub kolejny związek małżeński w ostatnim dziesięcioleciu XVIII wieku był niemal o 5 lat niższy (4 lata i 6 miesięcy) ${ }^{60}$. W latach 30. XIX stulecia średni wiek panów młodych w katolickiej parafii Mosty obniżył się do 38 lat i 8 miesięcy, ale w latach 70. odnotowano podwyższenie tego wskaźnika do 41 lat i 4 miesięcy. Stopniowe podnoszenie się wieku mężczyzn w chwili ponownego ślubu było zauważalne także na początku XX wieku, w którego pierwszej dekadzie wzrósł o ponad rok — do 42 lat i 5 miesięcy. Różnice ujawniły się w porównaniu danych katolickiej parafii Mosty z danymi dla całego Śląska habsburskiego. W latach 70. XIX stulecia wiek mężczyzn zawierających kolejne małżeństwo w parafii był o 4 lata i 4 miesiące wyższy, natomiast w latach 1901-1910 niższy nawet o 3 lata i 7 miesięcy ${ }^{61}$. Jeśli

\footnotetext{
59 L. Fialová: Století demografické statistiky..., s. 159-164.

60 L. Turoñ: Vývoj přirozené..., s. 45.

61 L. Dokoupil, L. Nesládková, R. Lipovski: Populace Rakouského Slezska..., s. 94-95.
} 
chodzi o drugie i kolejne małżeństwa zawierane przez kobiety, można zaobserwować niewielką zmienność $\mathrm{i}$ tendencje wzrostowe wieku panien młodych w chwili ślubu z 30 lat i 6 miesięcy w okresie 1791-1800 do 35 lat i 5 miesięcy w przedziale 1901-1910. Różnica wieku między panem młodym a panną młodą w chwili zawierania ponownych małżeństw oscylowała między 6-7 lat, a w latach 1791-1800 zaobserwowano najwyższą różnicę wieku, która wynosiła 11 lat i 3 miesiące.

\section{Sezonowość zawierania małżeństw}

W latach 1791-1910 małżeństwa zawierano najczęściej w lutym (473 związki małżeńskie, $28,00 \%$ wszystkich zawartych małżeństw). Kolejnym popularnym miesiącem był listopad, w którym w związek małżeński weszło 235 par (13,90\% wszystkich nowych małżeństw). W maju i styczniu liczba ślubów zbliżała się do 200 (11,10\% wszystkich nowo zawartych małżeństw), z kolei w lipcu, sierpniu, wrześniu i październiku sięgała ok. 100 (5,40-6,90\% wszystkich zawartych małżeństw). Najniższą liczbę ślubów zaobserwowano w kwietniu, marcu i grudniu. Powodem tego były przypadające $\mathrm{w}$ tych miesiącach kolejno: wielki post przed Wielkanocą, a także adwent i Boże Narodzenie.

\section{Liczba dzieci na jeden związek małżeński}

Na podstawie uzyskanych danych o narodzinach dzieci i liczbie zawartych małżeństw w parafii Mosty koło Jabłonkowa można oszacować liczbę dzieci urodzonych w jednym związku małżeńskim. W całym badanym okresie (1791-1910) na jedną parę małżeńską przypadało średnio 4,8 dziecka. W poszczególnych pięcioleciach wartości te wahały się w granicach od 3,1 do 7,8 dziecka na jeden związek małżeński (por. tabela 2).

Tabela 2

Liczba dzieci w jednym małżeństwie

w parafii katolickiej Mosty koło Jabłonkowa

\begin{tabular}{|c|c|c|c|}
\hline Okres & $\begin{array}{c}\text { Liczba } \\
\text { urodzonych } \\
\text { dzieci }\end{array}$ & $\begin{array}{c}\text { Liczba } \\
\text { zawartych } \\
\text { małżeństw }\end{array}$ & $\begin{array}{c}\text { Liczba dzieci } \\
\text { w jednym } \\
\text { małżeństwie }\end{array}$ \\
\hline 1 & 2 & 3 & 4 \\
\hline $1791-1795$ & 295 & 38 & 7,8 \\
\hline $1796-1800$ & 292 & 69 & 4,2 \\
\hline
\end{tabular}




\begin{tabular}{|c|c|c|c|}
\hline 1 & 2 & 3 & 4 \\
\hline $1801-1805$ & 276 & 55 & 5,0 \\
\hline $1806-1810$ & 267 & 53 & 5,0 \\
\hline $1811-1815$ & 271 & 62 & 4,4 \\
\hline $1816-1820$ & 273 & 55 & 5,0 \\
\hline $1821-1825$ & 297 & 51 & 5,8 \\
\hline $1826-1830$ & 310 & 68 & 4,6 \\
\hline $1831-1835$ & 306 & 64 & 4,8 \\
\hline $1836-1840$ & 287 & 50 & 5,7 \\
\hline $1841-1845$ & 271 & 57 & 4,8 \\
\hline $1846-1850$ & 248 & 78 & 3,2 \\
\hline $1851-1855$ & 236 & 50 & 4,7 \\
\hline $1856-1860$ & 285 & 72 & 4,0 \\
\hline $1861-1865$ & 306 & 67 & 4,6 \\
\hline $1866-1870$ & 359 & 115 & 3,1 \\
\hline $1871-1875$ & 392 & 79 & 5,0 \\
\hline $1876-1880$ & 385 & 88 & 4,4 \\
\hline $1881-1885$ & 404 & 64 & 6,3 \\
\hline $1886-1890$ & 394 & 71 & 5,5 \\
\hline $1891-1895$ & 468 & 89 & 5,3 \\
\hline $1896-1900$ & 490 & 90 & 5,4 \\
\hline $1901-1905$ & 478 & 98 & 4,9 \\
\hline $1906-1910$ & 514 & 105 & 4,9 \\
\hline Razem & 8104 & 1688 & 4,8 \\
\hline
\end{tabular}

Źródło: Archiwum Ziemskie w Opawie, Parafia Rzymskokatolicka Mosty koło Jabłonkowa, nr inw. 2939, sygn. Ja III 3 (lata 1786-1901), sygn. Ja III 9 (lata 1902-1947), metryki ślubów; ibidem, nr inw. 2937, sygn. Ja III 1 (lata 1786-1824), nr inw. 2938, sygn. Ja III 2 (lata 1825-1879), sygn. Ja III 6 (lata 1880-1921), metryki urodzonych.

Analiza rejestrów ślubów zawartych w katolickiej parafii Mosty koło Jabłonkowa w latach 1791-1910 pokazała, że rejestry parafii katolickich na ziemi cieszyńskiej są dobrym materiałem źródłowym do przeprowadzenia badań demograficznych. Uzyskany materiał warto wykorzystać do badań nad naturalnymi przemianami danej 
populacji w określonym czasie - nawet jeżeli pojawiają się trudności z dotarciem do rejestrów lub obawa, że uzyskane zapisy na temat liczby wiernych w poszczególnych parafiach Śląska Cieszyńskiego będą niedokładne.

Jestem przekonany, że zaprezentowane badania nad problemem małżeństwa w populacji parafii Mosty koło Jabłonkowa w okresie „długiego wieku XIX” udowodniły użyteczność analizy demograficznej, która pomogła odkryć, jak głęboko sięgały zmiany, do których doszło w związku z postępującymi procesami rewolucji przemysłowej. Ogólne współczynniki zawierania małżeństw w badanej populacji w większości przypadków były wyższe niż średnia dla ziem czeskich i Śląska austriackiego. Średnia wartość ogólnego współczynnika zawierania małżeństw na ziemiach czeskich wynosiła w całym XIX wieku 8,20\%o, w badanej populacji wartość ta była o 0,5 punktu promilowego wyższa. Współczynnik zawierania małżeństw dla Śląska austriackiego osiągał w latach 1871-1910 średnią wartość 8,10\%, a dane wyliczone dla parafii katolickiej były od niego wyższe o 0,7 punktu promilowego. Parafia w Mostach w badanym okresie była w znacznej mierze zależna od produkcji rolniczej, późniejsza transformacja w stronę produkcji przemysłowej przebiegała bardzo powoli. Rozwijający się w regionie przemysł ciężki, głównie trzynieckie huty, Ostrawsko-Karwińskie Zagłębie Węglowe, ale także Kolej Koszycko-Bogumińska, miały wpływ na populację parafii Mosty, przede wszystkim na przełomie XIX i XX wieku, kiedy to w zakładach tych znajdowało zajęcie coraz więcej ludności mieszkającej w badanej parafii, co w efekcie przełożyło się na wysokie wartości ogólnych współczynników zawierania małżeństw w tym czasie.

Liczba zawieranych małżeństw w parafii Mosty odchyliła się na przełomie XIX i XX wieku od powszechnej tendencji spadkowej wartości ogólnych współczynników zawierania małżeństw we wszystkich regionach monarchii habsburskiej. W katolickiej parafii Mosty odnotowano w latach 1891-1910 nieznacznie wyższą liczbę zawartych małżeństw, niż wskazywały dane dla ziem czeskich, Śląska austriackiego czy powiatu politycznego cieszyńskiego (różnica wynosiła 1,6 punktu promilowego).

Celem niniejszego artykułu jest wspieranie badań naturalnej przemiany populacji katolickich i ewangelickich parafii na Śląsku Cieszyńskim, która z historyczno-demograficznego punktu widzenia nie została opracowana pobieżnie. Badania te nie powinny się jednak ograniczać do zwykłego ilościowego opisywania rozwoju populacji na podstawie analizy rejestrów kościelnych. Przedmiotem zainteresowania powinna stać się także literatura tamtego okresu, która pozwoli lepiej zrozumieć mentalność mieszkańców badanej parafii w danym okresie. Badania nad rozwojem demograficznym powinno łączyć się z badaniami rozwoju gospodarczego, dzięki temu bowiem uda się zrekonstruować dokładniejszy i pełniejszy obraz procesów populacyjnych w ogóle. 


\section{Bibliografia}

DoкоupIL L.: Demografický vývoj ostravské průmyslové oblasti v období její geneze a počátečního vývoje: závěrečná výzkumná zpráva, úkol VIII-3-10/1. Pedagogická fakulta v Ostravě. Ostrava 1972.

Doкоupil L.: Dưsledky hladových let v polovině 19. století pro vývoj populace Těšinských Beskyd. „Sborník prací Pedagogické fakulty v Ostravě, řada C-10”. Ostrava 1975, s. 59-82.

DокоupIL L.: Obyvatelstvo ostravské prưmyslové oblasti do sčítání 1869. Praha 1987.

DокоupiL L.: Přirozený pohyb obyvatelstva a jeho úloha v populačním vývoji ostravské průmyslové oblasti v období její geneze a počátečního vývoje. Praha 1972.

DокоupiL L.: $Z$ díla historického demografa, Ostravská univerzita v Ostravě. Ostrava 2015.

Dokoupil L., Nesládková L., Lipovski R.: Populace Rakouského Slezska a severovýchodní Moravy vére modernizace. Ostrava 2014.

Fialová L.: Dějiny obyvatelstva českých zemí. Praha 1996.

Gaura K.: Mosty u Jablunkova v letech 1848-1918 (3. část). „Těšínsko 38” 1995, č. 1, s. 4-15.

Historia Śląska. T. 2: 1763-1850. Cz. 1: 1763-1806. Red. W. DŁugoвorski. Wrocław 1966.

Horský J., Seligová M.: Rodina našich předků. Praha 1997.

Jež R., Pindur D.: Mosty u Jablunkova včera a dnes. Mosty koło Jabłonkowa wczoraj i dziś. Český Těšín 2014.

KÁRNíková L.: Vývoj obyvatelstva v českých zemí 1754-1914. Praha 1965.

Litnerová Z.: Demografický vývoj Třinecka v letech 1839-1900 na příkladě Třince, Vendryně a Písečné. Diplomová práce na Pedagogické fakultě v Ostravě. Ostrava 1988.

Maur E.: Základy historické demografie. Praha 1978.

Morcinek G.: Śląsk. Cuda Polski. Poznań 1933.

MYšKa M.: Region a industrializace, studie k dějinám industrializace Slezska (1800-1918). Ostrava 2014.

Pitronová B.: Těšínsko v letech 1653-1848. W: Nástin dějin Těšínska. Oprac. M. Borák, D. GawrecKI. Praha-Ostrava 1992.

PopıoŁeK K.: Historia Śląska. Od pradziejów do 1945 roku. Katowice 1972.

Rachfalíková N.: Demografický vývoj obce Bukovec v letech 1795-1930. Diplomová práce na Pedagogické fakultě v Ostravě. Ostrava 1987.

Spyra J.: Śląsk Cieszyński w okresie 1653-1848. Cieszyn 2002.

STUDNICKI G.: Lidové zvyky a obyčeje na Těšinském Slezsku. Obrzędowość doroczna i rodzinna na Śląsku Cieszyńskim. Český Těšín 2011.

Šтika J., Stola Řík I., Tomolová V.: Těšínsko. 3. díl: Rodina a obec. Obyčeje. Lidové léčitelství. Český Těšín-Rožnov pod Radhoštěm 2001.

TuRoŇ L.: Vývoj přrirozené mèny obyvatelstva evangelické farnosti Bystřice nad Olší ve statistické éře. Diplomová práce na Katedře historie Filozofické fakulty Ostravské univerzity v Ostravě. Ostrava 2016.

Vochala J.: Slezská svatba. Popis a návod k pořádání slezské svatby na slavnostech. Polská Ostrava 1914. VyHLÍDAL J.: Slezská svatba. Opava 1894.

Wojtyla J.: Pamětní kniha Mostů u Jablunkova. 1. díl: Mosty u Jablunkova 1953-1977. Mosty u Jablunkova 1977. 


\section{Lukáš Turoň}

\section{Marriages of the inhabitants of Mosty koło Jabłonkowa parish during "the long 19th century"}

Summary

The article was written based on parish registers kept in Zemský archiv v Opavě and sources published in the 19th century. Issues regarding demographics in the territory of the Catholic parish of Mosty koło Jabłonkowa, such as: crude marriage rate, ratio of first, second and subsequent marriages, the age of newly-weds at the moment of entering into marriage, seasonality of marriages, and the number of children born inside a single marriage.

Overall coefficients related to entering into marriages in the Mosty parish were mostly higher than average values for Czech lands and Austrian Silesia lands. In Mosty the most numerous were first marriages whose number attained maximal value in the late 1860s and early 1870 s and at the beginning of the 20th century. It reflects the general tendency of gradual decrease in percentage of remarrying observed across Czech lands in the second half of the 19th and the beginning of the 20th century. Data from Mosty on the age of newly-weds at the moment of entering into marriage are analogous to the results regarding the entirety of Czech lands, yet the lowering of the age of entering into first marriage in the 1870s and at the beginning of the 20th century was characteristic of the parish in question. The findings of investigation into seasonality of marriages in Mosty in the years 1791-1910 are in line with the results obtained for Czech lands and Austrian Silesia - the marriages were concluded most frequently in February and January, often also in autumn (November). The lowest number of marriages was recorded in April, March, and December. Over the entire studied period (1791-1910) in the Catholic parish of Mosty on avarage 4.8 children were born per marriage, which was roughly the same as the results for Czech lands in general.

Key words: historical demography, matrimony, Catholic parish of Mosty koło Jabłonkowa 